\title{
Source Data Not Available
}

National Cancer Institute

\section{Source}

National Cancer Institute. Source Data Not Available. NCI Thesaurus. Code C67329.

Data from an original source is not present, accessible or ready for use or service. 